\title{
Effect of habitat selection on the dietary patterns of two triglid species
}

\author{
Mary Labropoulou $^{1, *}$, Athanasios Machias ${ }^{2}$ \\ ${ }^{1}$ Department of Biology, University of Crete, PO Box 2208, GR-71409 Iraklion, Crete, Greece \\ ${ }^{2}$ Institute of Marine Biology of Crete, PO Box 2214, GR-71003 Iraklion, Crete, Greece
}

\begin{abstract}
The distribution patterns and feeding habits of 2 triglids, Trigloporus lastoviza and Lepidotrigla cavillone, were investigated for fish collected in experimental trawl surveys carried out along the Cretan continental shelf over 4 yr. Despite their distribution overlap, depth and temperature selection differs considerably between species. T. lastoviza tended to select shallow depths and warm temperatures among those available, whereas $L$. cavillone was distributed throughout the exploited area and no significant temperature selection was found. Furthermore, no evidence of any size-depth relationship in either fish species was detected. Stomach content analysis revealed that both species were carnivores, feeding mainly on benthic invertebrates, and that each species consumed a narrow range of prey species with no significant dietary overlap. Classification and ordination of the gravimetric and numerical contributions of prey species in their diets demonstrated that the dietary samples of the 2 species were distinct. Interspecific dietary overlap was less than intraspecific overlap between size classes and between months. Trophic diversity was higher for $T$. lastoviza and increased significantly with fish size, while no effect of size on the low dietary breadth of $L$. cavillone was found. Species differences in preference and utilization of prey are related to their distribution patterns. In particular, $T$ lastoviza exhibited the most restricted distribution and appeared to have a broader trophic niche than L. cavillone, which occurs in a wider depth range. The results suggest that the ability of these species to exploit particular habitats and/or specific prey characteristics is an important feature of predator foraging that allows them to segregate their feeding niche at the depth range at which they co-occur.
\end{abstract}

KEY WORDS: Triglidae - Depth selection - Temperature selection - Ontogeny - Prey selection . Resource partitioning - Niche

\section{INTRODUCTION}

Strategies used by related groups of animals in exploiting resources are of continuing interest in ecological studies. There is evidence that in fish assemblages, in contrast to the situation with terrestrial vertebrates, food partitioning is more important than habitat partitioning (Schoener 1974, Ross 1986). Changes in diet and/or habitat during ontogeny are extremely common in fishes (Werner \& Gilliam 1984). Fish can partition food resources between species as well as between size classes within a species. Similar proximate mechanisms can underline subdivision of

\footnotetext{
- Present address: National Center lor Marine Research, Agios Kosmas, GR-16604 Hellinikon, Greece.

E-mail:mlabro@posidon.ncmr.ariadne-t.gr
}

food resources in both cases. These include differences in morphology, foraging behaviour, period of activity and habitat use (Werner 1979, Mittelbach 1981, Ross 1986, Norton 1991). However, different ecological processes have been emphasized in interpreting the adaptive value of resource partitioning in these 2 situations. Partitioning among species has been argued to reduce interspecific competition (Sale 1979, Osenberg et al. 1992, Schluter 1994). By contrast, differential vulnerability to predators and/or the ability to exploit prey may lead to de facto partitioning of prey among size classes within a species, with the consequence that intraspecific competition is reduced (Werner et al. 1983). Although choice of habitats and food by a fish species can be modified substantially by intra- and interspecific interactions (Werner \& Hall 1979, Werner \& Mittelbach 1981, Werner \& Gilliam 1984), which 


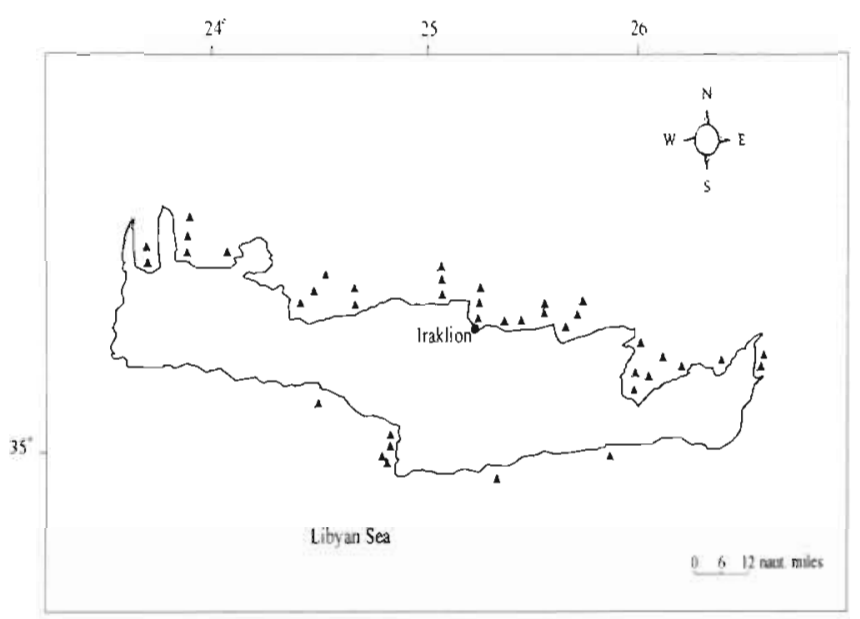

Fig. 1. Location of the sampling stations on the Cretan shelf

have important ecological and fisheries implications (Werner 1980), the significance and dynamics of such interactions remain almost unknown in many aquatic environments.

The triglids are marine, demersal fish widely distributed in tropical and temperate seas (Whitehead et al. 1986). Aspects of the biology of triglids suggest that they have a generalistic and opportunistic life-history character. Limited available studies regarding habitat preferences report that they are found over a variety of soft sediments such as mud, sand and low-profile reef with interspersed mud and sand depressions (Ross 1977, Papaconstantinou 1983, Booth 1997). The few studies on feeding biology in the family suggest that the species studied are opportunistic, feeding on a wide range of available epibenthic and infaunal invertebrates (Ross 1977, 1978, Caragitsou \& Papaconstantinou 1990, Meyer \& Smale 1991, Colloca et al. 1994).

The triglids Trigloporus lastoviza and Lepidotrigla cavillone are both very abundant on the Cretan continental sheif and are a frequent by-catch of inshore trawl fisheries (Tsimenides et al. 1991, 1992). In order to investigate whether these closely related species differ in their utilization of resources, a 4 yr study was undertaken to determine habitat use and dietary patterns of both species and to elucidate how any possible habitat differences can influence these feeding modes.

\section{MATERIAL AND METHODS}

Study area and sampling procedure. A 3 yr survey on the distribution of the triglids was carried out along the Cretan continental shelf from August 1988 to April 1991. Nine seasonal experimental bottom trawl survey cruises were conducted by the Institute of Marine Biol- ogy of Crete at 40 fixed sampling stations selected to cover all the trawlable fishing grounds of the region (Fig. 1). Details of survey design and sampling procedure are given by Tsimenides et al. (1991).

The collected data included abundance and biomass of the fishes caught and supporting data on depth, temperature and salinity. The cruise periods were as follows: Iate August to early September (summer), December (winter) and late March to early April (spring). The sampling stations were distributed over 3 distinct depth zones: 26-70 $\mathrm{m}$ (zone I), 71-150 m (zone II) and 151-350 $\mathrm{m}$ (zone III). Zone I covered $25 \%$, zone II $24 \%$ and zone III $51 \%$ of the total study area. Algae and marine angiosperms, mainly Caulerpa prolifera, Posidonia oceanica and Halophila stipulacea, dominated the sand-silt substrate in zone $I_{i}$ the substrate of zone II was muddy, consisting mostly of mud, and the substrate of zone III was covered for the most part by the crinoid Leptometra phalangium. All tows were carried out approximately in parallel to the isobaths of either 100 or $200 \mathrm{~m}$ during daytime. Complementary monthly samples (excepting January) from August 1990 to August 1992 were also taken from experimental trawl surveys in Iraklion Bay for stomach content analysis. The samples were collected from 3 fixed stations which were selected to cover all the trawlable fishing grounds of the region between 25 to $150 \mathrm{~m}$ depth. All samples were taken during the day between 8:30 and 10:30 h.

The trawl used was equipped with a cod-end bag liner of $22 \mathrm{~mm}$ stretched mesh size. The duration of each haul (bottom time) was 50 to $90 \mathrm{~min}$ and the trawling speed fluctuated from 1.8 to 3 knots, depending on the depth and the nature of the bottom. Since all trawls were carried out using the RV 'Philia' it was assumed that gear selectivity was constant. Bottom temperature and salinity were measured using a SEABIRD CTD unit. The measurements recorded for the $5 \mathrm{~m}$ above the bottom at each station were averaged and the resulting values were considered as the temperature and salinity at the specific station.

Laboratory methods. Stomach contents of the triglids were examined for up to a total of 20 to 30 specimens per species for each haul and station. When catches were higher, the fish were separated into size intervals, then proportionally subsampled until a total of 30 fish were selected for stomach analysis. The samples were fixed on board, immediately after capture, in $10 \%$ buffered formalin, measured to the nearest $\mathrm{mm}$ (total length) and weighed to the nearest $0.1 \mathrm{~g}$. Thereafter, the stomachs were removed and the contents wet weighed. Where possible, prey items were identified to species or the nearest possible taxonomic level, counted under a binocular microscope, weighed to the nearest $0.01 \mathrm{~g}$ and measured to the nearest $0.1 \mathrm{~mm}$. 
Data analysis. Following the procedure described by Carrothers (1980), the door spread of the trawl net was calculated for each haul and then multiplied by the speed of the boat and fishing time to estimate the total surface sampled. Subsequently the abundance of fish caught was expressed as number of individuals per square nautical mile (n mile ${ }^{2}$ ), making it possible to compare fish abundances between sampling stations.

After logarithmic transformation (Middleton \& Musick 1986, Stefanescu et al. 1992), mean abundance (number $n$ mile $^{-2}$ ) and mean biomass ( $\mathrm{g} \mathrm{n}$ mile ${ }^{-2}$ ) were calculated for each cruise per zone (I, II, III). Furthermore, the seasonal distribution of the total abundance and biomass in each zone or bottom depth interval was calculated by weighting the mean values with the ratio of the zone's or interval's surface area to the total area.

Analysis of variance showed no differences in the mean abundance and mean biomass among the 3 surveys in each season, nor among the 3 zones (I, II, III) in the same season $(0.17<p<0.81$, Bartlett's test $0.15<p<$ 0.62 ). For each season, results and conclusions were similar, independent of whether survey-specific or pooled data were used. Hence, only the latter are presented here.

A correlation analysis (Pearson correlation coefficient) was performed to test the hypothesis that fish size is depth dependent. Fish size was also tested for any significant correlation with temperature. To test the hypotheses 'bigger individuals tend to be found in deeper water' and 'smaller fish tend to be found in shallow water', correlation analysis was performed between depth and minimum or maximum length (Middleton \& Musick 1986, MacPherson \& Duarte 1991, Stefanescu et al. 1992). The same variables were used in correlation analysis with respect to temperature.

The distribution and habitat selection of the fish species examined were simplified as follows. We examined relationships among each species density (fish n mile $^{-2}$ ) and temperature or bottom depth using cumulative distribution functions (CDFs) following Perry \& Smiths (1994). The CDF (in \%) for temperature (available temperature) or bottom depth (available depths) was calculated for each season as follows:

$$
f(t)=100 \frac{\sum_{h=1}^{L} \sum_{i=1}^{n_{h}} \frac{A_{h}}{n_{h}} I}{\sum_{h=1}^{L} \sum_{l=1}^{n_{h}} \frac{A_{h}}{n_{h}} I} \text { where } I=\left\{\begin{array}{l}
1 \text { if } x_{h l}<t \\
0 \text { otherwise }
\end{array}\right.
$$

where $t$ is a level of temperature or bottom depth, $A_{h}$ is the area of zone $h, n_{h}$ is the number of tows in zone $h$, $x_{h}$ is the bottom temperature or depth of tow $i$ in zone $h$ and $L$ is the number of zones. The CDF for each species catch was calculated similarly:

$$
g(t)=100 \frac{\sum_{h=1}^{L} \sum_{i=1}^{n_{h}} \frac{A_{h}}{n_{h}} y_{h i} I}{\sum_{h=1}^{L} \sum_{i=1}^{p_{h}} \frac{A_{h}}{n_{h}} y_{h l} I} \text { where } I=\left\{\begin{array}{l}
1 \text { if } x_{h i}<t \\
0 \text { otherwise }
\end{array}\right.
$$

where $y_{h i}$ is the number of each species caught in tow $i$ in zone $h$. We calculated the CDF separately for Trigloporus lastoviza and Lepidotrigla cavillone (Swain \& Krammer 1995).

To examine seasonal variation in temperature or bottom depth selection by the triglids, we compared CDFs of temperature and triglid catch in relation to temperature, as well as CDFs of bottom depth and triglid catch in relation to bottom depth. We calculated

$$
S=\sum_{t=1}^{t}[f(t)-g(t)]
$$

for each season and species. $S$ compares average available temperature or depth to the average temperature or depth selected by the species. Positive values of $S$ indicated selection of relatively warm temperatures or deeper waters within the ranges studied here. We used a Kolmogorov-Smirnov type of statistic to test the significance of temperature and bottom depth selection. The test statistic $D$ was $D=\max |f(t)-g(t)|$ (the maximum absolute vertical distance), with the 2 functions compared at $0.2^{\circ} \mathrm{C}$ (CDFs of temperature) or $10 \mathrm{~m}$ (CDFs of depth) intervals. Significance was assessed using randomization tests (Perry \& Smiths 1994, Swain \& Krammer 1995).

The cumulative distribution $f(t)$ was used to identify the median depths and temperature available to each species and the limits of the available temperatures and depths [i.e. 2.5 and 97.5 percentiles of $f(t)$ ] during the surveys. $g(t)$ was used to define the median and the limits of depths and temperatures occupied by species. Following Rose \& Leggett (1988, 1989), we defined these limits as the range within which $95 \%$ of each species occurred, i.e. the 2.5 and 97.5 percentiles of each species catch in relation to temperature and depth.

The contribution of prey items in the fish diet was estimated using both the numerical abundance and the biomass of prey items in stomachs (Berg 1979, Hyslop 1980, Bowen 1983). In order to evaluate size related variations in food habits, specimens of each fish species were separated into $20 \mathrm{~mm}$ size classes for Trigloporus lastoviza and $10 \mathrm{~mm}$ size classes for Lepidotrigla cavillone. Total length of $T$ lastoviza specimens examined for stomach content analysis ranged from 57 to $250 \mathrm{~mm}$, mean ( $\pm \mathrm{SD}$ ) length was $133.1 \pm$ $36.4 \mathrm{~mm}$. For $L$. Cavillone, total length ranged from 64 to $176 \mathrm{~mm}$, mean $( \pm \mathrm{SD})$ length was $111.7 \pm 10.8$.

Dietary breadth was calculated using Levin's standardized index (Hurlbert 1978, Krebs 1989): 


$$
B_{i}=\frac{1}{n-1}\left(\frac{1}{\Sigma_{j} p_{i j}^{2}}-1\right)
$$

where $B_{i}=$ Levin's standardized index for predator $i$, $p_{i j}=$ proportion of diet of predator $i$ that is made up of prey $j$, and $n=$ number of prey categories. This index ranges from 0 to 1 , with low values indicating diets dominated by a few prey items (specialist predators) and higher values indicating generalist diets (Gibson \& Ezzi 1987, Krebs 1989).

Dietary overlap between the size classes was calculated using the simplified Morisita's index (Krebs 1989, Hall et al. 1990):

$$
C_{i k}=\frac{2 \Sigma_{j} p_{i j} p_{k j}}{\sum_{j} p_{i j}^{2}+\Sigma_{j} p_{k j}^{2}}
$$

where $\mathrm{C}_{1 k}=$ simplified Morisita's index for predators $i$ and $k_{1}$ and $p_{1 j}$ and $p_{k j}=$ proportions of predator $i$ and $k$ with prey $j$ in their stomachs. Dietary overlap increases as the Morisita's index increases from 0 to 1. Overlap is generally considered to be biologically significant when the value exceeds 0.60 (Keast 1978 , MacPherson 1981, Wallace 1981, Langton 1982). Dietary breadth and overlap were estimated using the nu-

Table 1. Available depth and temperature and occupied depth and temperature, by species, as well as the minimum

\begin{tabular}{|c|c|c|c|c|}
\hline Percentile & Season & Available & $\begin{array}{c}\text { Trigloporus } \\
\text { lastoviza }\end{array}$ & $\begin{array}{c}\text { Lepidotrigla } \\
\text { cavillone }\end{array}$ \\
\hline \multicolumn{5}{|l|}{ Depth (m) } \\
\hline \multirow[t]{3}{*}{$2.5 \%$} & Spring & 30 & 30 & 30 \\
\hline & Summer & 30 & 30 & 44 \\
\hline & Winter & 30 & 30 & 32 \\
\hline \multirow[t]{3}{*}{$50 \%$} & Spring & 155 & 56 & 154 \\
\hline & Summer & 145 & 56 & 150 \\
\hline & Winter & 145 & 57 & 144 \\
\hline \multirow[t]{3}{*}{$97.5 \%$} & Spring & 315 & 165 & 238 \\
\hline & Summer & 275 & 125 & 245 \\
\hline & Winter & 305 & 95 & 190 \\
\hline \multicolumn{5}{|c|}{ Temperature $\left({ }^{\circ} \mathrm{C}\right)$} \\
\hline \multirow[t]{3}{*}{$2.5 \%$} & Spring & 14.6 & 14.6 & 14.6 \\
\hline & Summer & 14.6 & 16.0 & 14.6 \\
\hline & Winter & 13.8 & 16.0 & 14.4 \\
\hline \multirow[t]{3}{*}{$50 \%$} & Spring & 14.8 & 15.9 & 14.7 \\
\hline & Summer & 15.1 & 19.4 & 15.2 \\
\hline & Winter & 15.8 & 16.7 & 15.9 \\
\hline \multirow[t]{3}{*}{$97.5 \%$} & Spring & 17.0 & 17.3 & 15.9 \\
\hline & Summer & 24.0 & 24.0 & 23.4 \\
\hline & Winter & 17.8 & 17.9 & 17.9 \\
\hline \multicolumn{5}{|l|}{ Salinity $(\%)$} \\
\hline \multirow[t]{3}{*}{ Min. } & Spring & 38.65 & 38.65 & 38.65 \\
\hline & Summer & 38.12 & 38.12 & 38.12 \\
\hline & Winter & 38.66 & 38.66 & 38.66 \\
\hline \multirow[t]{3}{*}{ Max. } & Spring & 39.05 & 39.05 & 39.05 \\
\hline & Summer & 39.75 & 39.75 & 39.75 \\
\hline & Winter & 39.23 & 39.23 & 39.23 \\
\hline
\end{tabular}
and maximum salinity during each season merical abundance and the biomass of prey items found in the stomachs. Bias-corrected bootstrap $95 \%$ confidence intervals, based on 1000 simulations, were used to estimate the reliability of these indices (Efron \& Tibshirani 1986, Hall et al. 1990). Cluster analysis (group average) employing the Bray-Curtis similarity index (Field et al. 1982) was performed on the standardized abundance and biomass values of prey species to describe ontogenetic, seasonal and interspecific variations in food habits using the PRIMER algorithms (Plymouth Marine Laboratory). Multidimensional Scaling (MDS) ordination analysis was also performed with the same configuration as in cluster analysis with respect to similarity index and transformation.

Differences in dietary composition and stomach fullness by size and month were tested by $\chi^{2}$ on combined data for both years, because diet did not vary significantly between the 2 years. The logit model used to investigate monthly variations in the proportion of full/empty stomachs, as a function of fish size, was

$$
\log \left[p_{d} /\left(p_{d}-1\right)\right]=a_{d}+b_{d} L+e
$$

where $p_{d}$ is the probability that a stomach is non-empty in month $d, L$ is the fish length and $e$ is the error term. One-way ANOVAs were used to compare the mean number, the mean weight and the mean size of prey items among the size classes, and the a posteriori Tukey's test was employed to locate the source of any differences (Zar 1984). The numbers and weights of prey items were log transformed to remove the dependency of the variance on the mean (Zar 1984). Mean number and mean weight of prey per fish in each size class was based only on specimens with food items in the stomach. All statistical inferences were based on the 0.05 significance level.

\section{RESULTS}

\section{Distribution patterns}

The available and occupied temperature and bottom depth for Trigloporus lastoviza and Lepidotrigla cavillone in each season are given in Table 1. T. lastoviza was distributed from 30 to $165 \mathrm{~m}$ depth, between temperatures of 14.6 and $24^{\circ} \mathrm{C}$ and between salinities of 38.12 and $39.75 \%$. L. cavillone was found to occur from 30 to $245 \mathrm{~m}$ depth, between temperatures of 14.6 and $23.4^{\circ} \mathrm{C}$ and between salinities of 38.12 and $39.75 \%$. Salinity showed very small variation, and is not generally considered to affect the distribution of fishes on the Cretan shelf (Tsimenides et al. 1991).

The distribution of triglids by depth intervals indicated that, although both species generally occurred in 
all zones, there is a considerable variation of their abundance and biomass over the depth ranges examined. Trigloporus lastoviza was found in shallower depths up to $100 \mathrm{~m}$, while Lepidotrigla cavillone was distributed throughout the exploited area (Figs. 2 \& 3a). A randomization test based on the maximum vertical distance between CDFs indicated significant shallow depth selection only for $T$. lastoviza (test statistic $D$, $\mathrm{p}<0.05$ ).

Temperature selection of triglids indicated a pattern consistent with the depth distribution pattern (Fig. 3b). A randomization test indicated significant selection of warm temperatures relative to those available for Trigloporus lastoviza during the winter $(D=55.13$, $\mathrm{p}<$ $0.05)$ but it did not indicate any significant temperature selection for Lepidotrigla cavillone (test statistic $D, p<$ 0.05 ).

The relationship between the maximum and minimum total length and depth was significant only for Lepidotrigla cavillone in summer $(\mathrm{r}=0.65, \mathrm{p}<0.001)$, while no significant relationships were found for Trigloporus lastoviza. No significant correlations were found between minimum total length and temperature for either species, whereas significant correlation between maximum total length and temperature was found in spring for T. lastoviza $(r=0.78, p<0.05)$ and in summer for $L$. Cavillone $(\mathrm{r}=0.68, \mathrm{p}<$ $0.001)$

\section{Feeding intensity}

Food was found in 318 of the 396 stomachs (80.3\%) of Trigloporus lastoviza and in 572 of the 694 stomachs (82.4\%) of Lepidotrigla cavillone which were examined. The proportion of empty stomachs varied significantly among the size classes of $T$. lastoviza $\left(\chi^{2}=25.7, p<0.001\right)$. The logit model revealed that the interaction between month and fish size for the probability that a stomach is non-empty was significant $\left(F_{29.367}=\right.$ 2.88, $p<0.001)$. The slope was always $>0$, indicating a positive allometry on full stomachs for $T$. lastoviza. The estimated probabilities did not differ significantly between the 2 years of the study $(t$-test $=1.22, p>$ $0.05)$.

No significant differences were found for the proportion of empty stomachs among the size classes of Lepidotrigla cavillone $\left(\chi^{2}=\right.$ $13.54, \mathrm{p}>0.05$ ), while the logit model did not indicate any significant effect of month and/or fish size on full stomachs $\left(F_{35,659}=\right.$ $1.03, \mathrm{p}>0.05$ ).

\section{Composition of diet}

Both species were carnivorous, feeding mainly on benthic invertebrates. Decapods clearly dominated the diet of Trigloporus lastoviza, forming $58.3 \%$ by number and $91.2 \%$ by weight of its diet. Mysids were the most important prey by number $(49.4 \%)$ in the diet of Lepidotrigla cavillone while decapods made up the $55 \%$ of the total weight of its stomach contents. Small crustaceans were also found in the diets of both fish species, but their contribution by number and by weight was comparatively low.

The 51 and 35 different prey species identified for Trigloporus lastoviza and Lepidotrigla cavillone, respectively, consisted mainly of representatives of 3 major groups (mysids, small crustaceans and decapods). However, only a few prey species were found at high percentages in the diet of each of the fish species (Table 2). The carid decapod Philocheras monacanthus predominated in the diet of $T$. lastoviza by number, whereas the crabs Liocarcinus arcuatus and Liocarcinus maculatus made by far the greatest contribution by weight in the diet of this species. Philocheras bispinosus was the major prey species in terms of both number and weight, and was found exclusively in the diet of L. Cavillone.
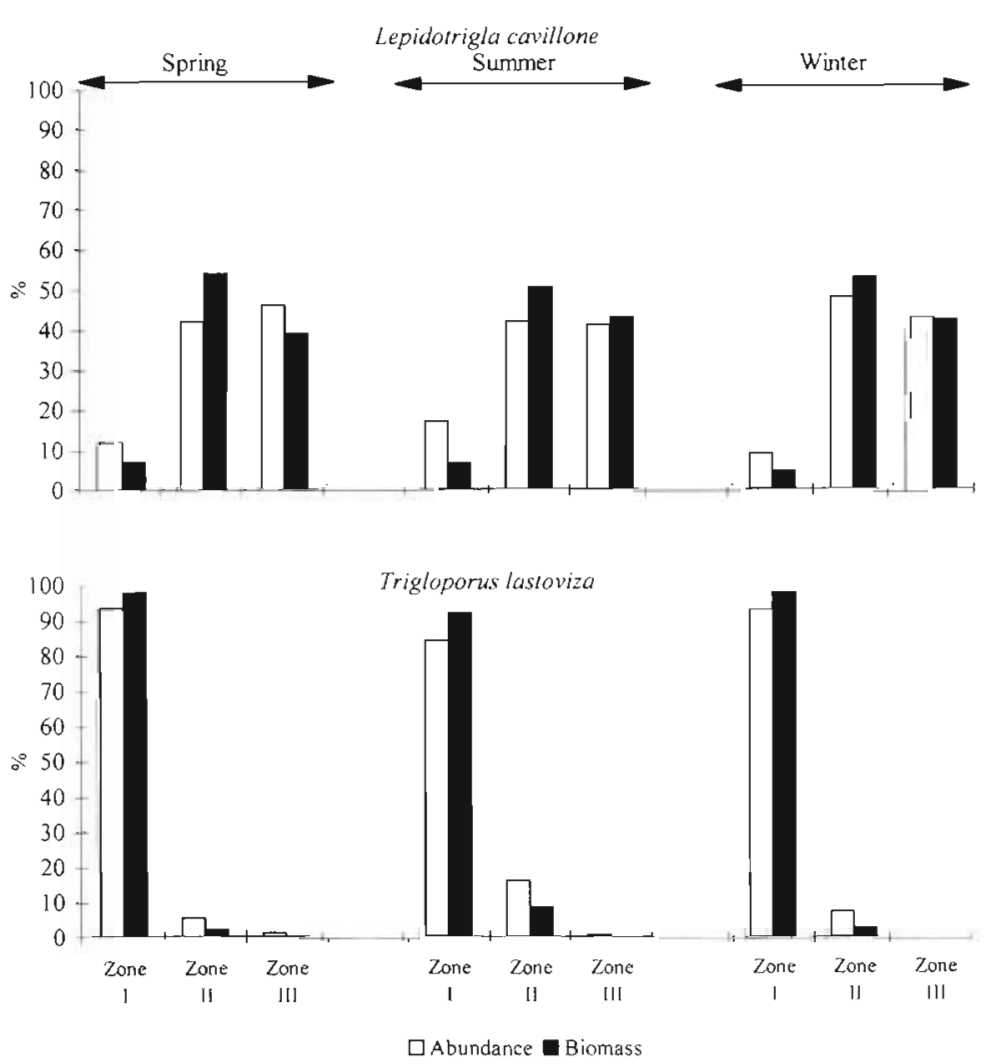

Fig. 2. Seasonal distribution (\%) of Lepidotrigla cavillone and Trigloporus lastoviza in different depth ranges on the Cretan shelf 
a

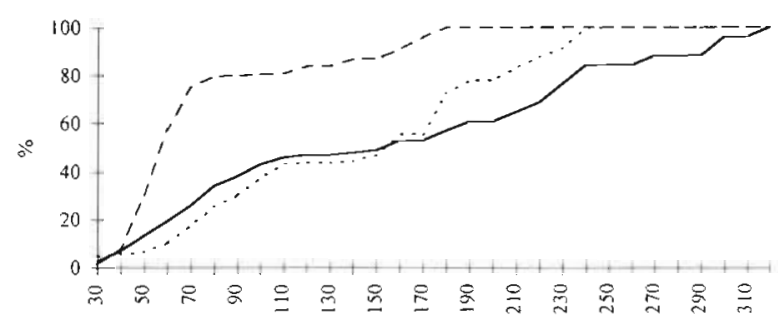

SUMMER

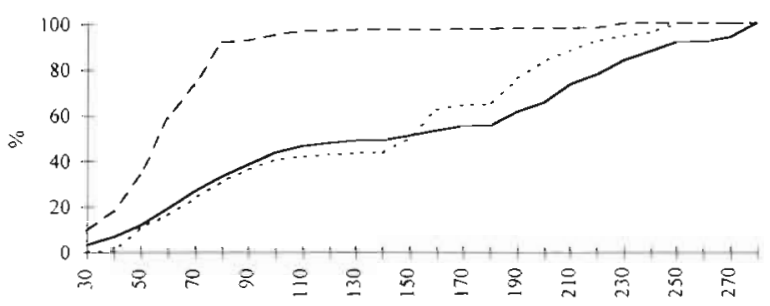

WINTER

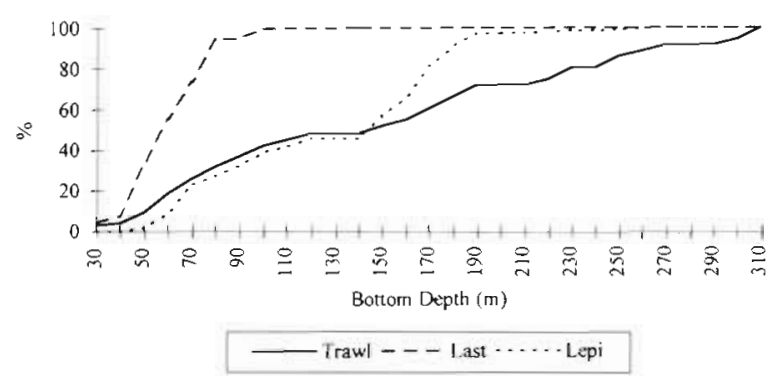

b
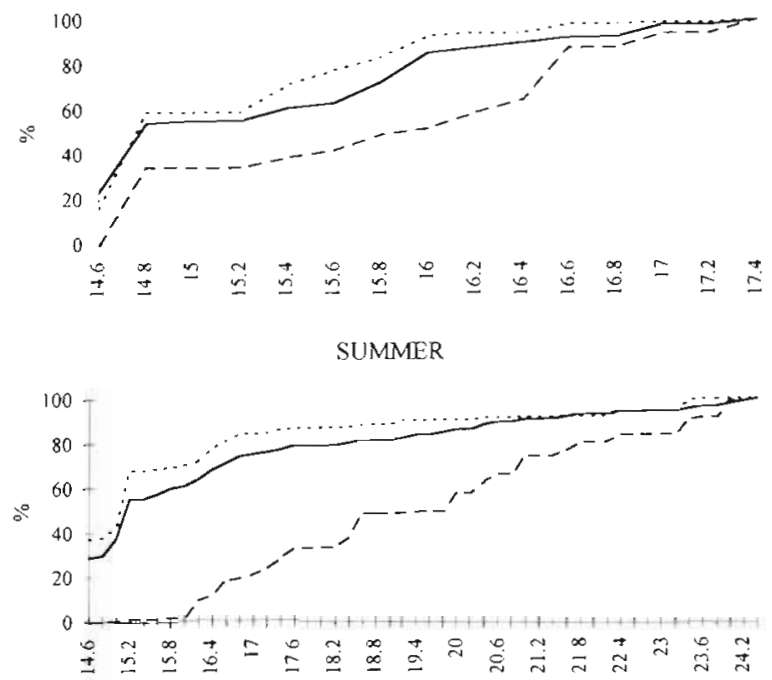

WINTER



Fig. 3. Cumulative distribution function by season for the observed (Trawl). Trigloporus lastoviza (Last) and Lepidotrigla cavillone (Lepi) (a) depth and (b) temperature on the Cretan shelf

Mean dietary breadth as indicated by Levin's standardized index was $0.34( \pm 0.04)$ and $0.26( \pm 0.04)$ for Trigloporus lastoviza and $0.25( \pm 0.02)$ and $0.21( \pm 0.03)$ for Lepidotrigla cavillone in terms of numerical abundance and biomass of prey, respectively.

\section{Food in relation to fish size}

The occurrence of the prey species in the diet varied significantly among the size classes of each fish examined only for the ingestion of amphipods $\left(\chi^{2}=75.01\right.$, $\mathrm{p}<0.001)$, Liocarcinus arcuatus $\left(\chi^{2}=32.62, \mathrm{p}<0.001\right)$ and Liocarcinus maculatus $\left(\chi^{2}=41.97, p<0.001\right)$ for Trigloporus lastoviza, and of crab megalops $\left(\chi^{2}=18.21\right.$, $\mathrm{p}<0.05)$ for Lepidotrigla cavillone. Amphipods occurred in the smaller specimens of $T$ lastoviza (total length, TL $<110 \mathrm{~mm}$ ), while $L$. maculatus and $L$. arcuatus were found at high percentages in the diet of specimens larger than $110 \mathrm{~mm}$ TL. The contribution of juvenile crabs (megalops) in the diet of $L$. cavillone increased with fish size, with the highest contribution in specimens larger than $121 \mathrm{~mm}$ TL.

The total amount of food ingested, as indicated by the mean weight of stomach contents varied significantly among the size classes of Trigloporus lastoviza $\left(F_{7,307}=21.01, p<0.001\right)$. Pair-wise group comparisons showed the existence of 2 homogeneous groups: the mean consumption rate per individual (i.e. g food per size class) increased with increasing size, with fish up to $170 \mathrm{~mm}$ TL exhibiting the lowest consumption rate Significant differences also emerged among size classes of $T$. lastoviza when the mean number of prey items per stomach was examined $\left(F_{7,307}=12.74, \mathrm{p}<\right.$ 0.001 ). The mean number of prey items consumed by fish larger than $91 \mathrm{~mm}$ TL was less than the number consumed by smaller specimens. In contrast, no significant differences emerged among the size classes of Lepidotrigla cavillone when the mean number $\left(F_{6,549}=\right.$ $1.24, p>0.05$ ) of prey items per stomach was examined; however, the mean weight significantly increased with fish size $\left(F_{6,549}=2.42, \mathrm{p}<0.05\right)$. Fish size 
Table 2. Percentage contribution by number $(n)$ and by weight $(w)$ of the major prey taxa and species in the diet of Trigloporus lastoviza and Lepidotrigla cavillone from the Cretan shelf. Prey occurring in $>1 \%$ of the total are given $(+:<1 \%,-$ : absent)

\begin{tabular}{|c|c|c|c|c|}
\hline \multirow[t]{2}{*}{ Prey category } & \multicolumn{2}{|c|}{$\begin{array}{c}\text { Trigloporus } \\
\text { lastoviza }\end{array}$} & \multicolumn{2}{|c|}{$\begin{array}{l}\text { Lepidotrigla } \\
\text { cavillone }\end{array}$} \\
\hline & $n$ & $w$ & $n$ & $w$ \\
\hline Mysids & 31.61 & 2.43 & 49.44 & 41.52 \\
\hline Polychaetes & + & + & + & + \\
\hline Molluscs & + & + & + & + \\
\hline Echinoderms & + & + & - & - \\
\hline Fish & + & + & + & + \\
\hline \multicolumn{5}{|l|}{ Small crustaceans } \\
\hline Monoculodes gibbosus & 2.69 & + & - & -- \\
\hline Perioculodes longimanus & - & - & 6.03 & 1.04 \\
\hline Westwoodilla rectirostris & 3.25 & + & - & - \\
\hline Iphinoe serrata & 1.2 & + & _- & _- \\
\hline Campylaspis glabra & - & - & 2.40 & + \\
\hline Other species & 1.63 & + & 2.91 & + \\
\hline Total small crustaceans & 8.77 & 0.20 & 11.34 & 2.66 \\
\hline \multicolumn{5}{|l|}{ Decapods } \\
\hline Philocheras bispinosus & - & - & 23.79 & 28.09 \\
\hline Philocheras monacanthus & 23.81 & 3.07 & - & - \\
\hline Philocheras sculptus & 1.01 & + & - & - \\
\hline Pontocaris lacazei & + & 3.76 & + & 1.06 \\
\hline Sicyonia carinata & + & 4.27 & - & - \\
\hline Processa nouveli & _- & - & 1.82 & 2.79 \\
\hline Solenocera membranacea & - & - & + & 2.89 \\
\hline Scyllarus arctus & _- & _- & + & 2.36 \\
\hline Scyllarus pygmaeus & + & 2.76 & + & 1.09 \\
\hline Upogebia tipica & + & 1.29 & + & 3.07 \\
\hline Megalopa Upogebia tipica & + & + & 2.02 & 1.10 \\
\hline Paquridae & + & + & + & 1.50 \\
\hline Megalopa Paguridae & + & + & 1.25 & + \\
\hline Ethusa mascarone & 5.99 & 14.70 & - & - \\
\hline Eurinome aspera & + & 1.03 & _- & - \\
\hline Inachus communissimus & 1.47 & 1.97 & - & - \\
\hline Liocarcinus arcuatus & 5.94 & 17.14 & _- & _- \\
\hline Liocarcinus maculatus & 9.65 & 29.59 & - & - \\
\hline Macropodia rostrata & 1.63 & 2.29 & - & _- \\
\hline Palicus caroni & + & 2.13 & - & - \\
\hline Parthenope massena & 3.32 & 4.92 & _- & _- \\
\hline Megalopa Brachyura & + & + & 8.06 & 8.46 \\
\hline Other species & 1.41 & 1.01 & + & 1.80 \\
\hline Total decapods & 58.31 & 91.20 & 38.63 & 54.99 \\
\hline Others & + & 5.59 & - & - \\
\hline
\end{tabular}

was associated with an increase in the diversity for $T$. lastoviza $\left(F_{7,307}=6.48, \mathrm{p}<0.001\right)$, while no significant effect of fish size on the diversity was found for $L$. CaVillone specimens $\left(F_{6,549}=1.03, p>0.05\right)$.

Cluster analysis run on trophic data for each of the fish species using both the numerical abundance and the biomass of prey species revealed the existence of size-specific feeding classes according to similar dietary habits within a given species (Fig. 4). Both species were characterized by similar feeding patterns, namely different feeding habits between small and large individuals, but differed in their size boundaries. However, 2 major groups were discriminated, each one consisting entirely of the specimens of each species examined. At the species level mysids, Philocheras bispinosus and crab megalops contributed most $(70 \%)$ to the similarities within group I, whereas Liocarcinus maculatus, Philocheras monacanthus, Ethusa mascarone and Parthenope massena contributed $60 \%$ to the similarity of group II. Mean intraspecific dietary overlap was greater than mean interspecific overlap, which did not exceed $40 \%$. Hence, this analysis indicated that interspecific differences in diet were greater than differences between size classes of the same species, irrespective of the resource matrix used.

\section{Seasonal variation in dietary composition}

Diet composition was fairly consistent over the months as indicated by the percentage contribution by number and weight of the main prey categories (Fig. 5). By considering the abundance and biomass of all prey species in fish diets on a monthly basis, cluster analysis revealed 2 groups, each one corresponding to the monthly samples of each fish species (Fig, 6). Prey species contributing most to the similarity of each group were mysids, Philocheras bispinosus and crab megalops for group I and Liocarcinus maculatus, Philocheras monacanthus, Ethusa mascarone and Parthenope massena for group II. This analysis, however, indicated that despite the seasonal variation in prey consumption exhibited by each species, interspecific variation was more pronounced, suggesting that the choice of prey types by each species was relatively consistent over the year.

Dietary breadth for each species showed no significant overall effect of season (ANOVA tests, $p>0.05$ ). Although seasonal influences were also examined as a function of fish size, no significant differences were found in size composition of the specimens for either species throughout the year (ANOVA tests, $p>0.05$ ).

\section{Resource partitioning between fish species}

Of the 79 different prey species found in the stomachs, only 7 occurred in the diet of both triglids. The values for dietary overlap between the fish species, as measured by Morisita's index were low $(<0.60)$, indicating that they exploited different prey species (Table 3). Furthermore the analysis of variance on the mean prey sizes consumed by the 2 triglids revealed significant differences $\left(F_{1,910}=34.60, p<0.001\right)$. Trigloporus lastoviza exploited prey with the smallest mean size $(7.93 \pm 4.78 \mathrm{~mm})$, while Lepidotrigla cavillone consumed prey at $9.7 \pm 4.19 \mathrm{~mm}$. 

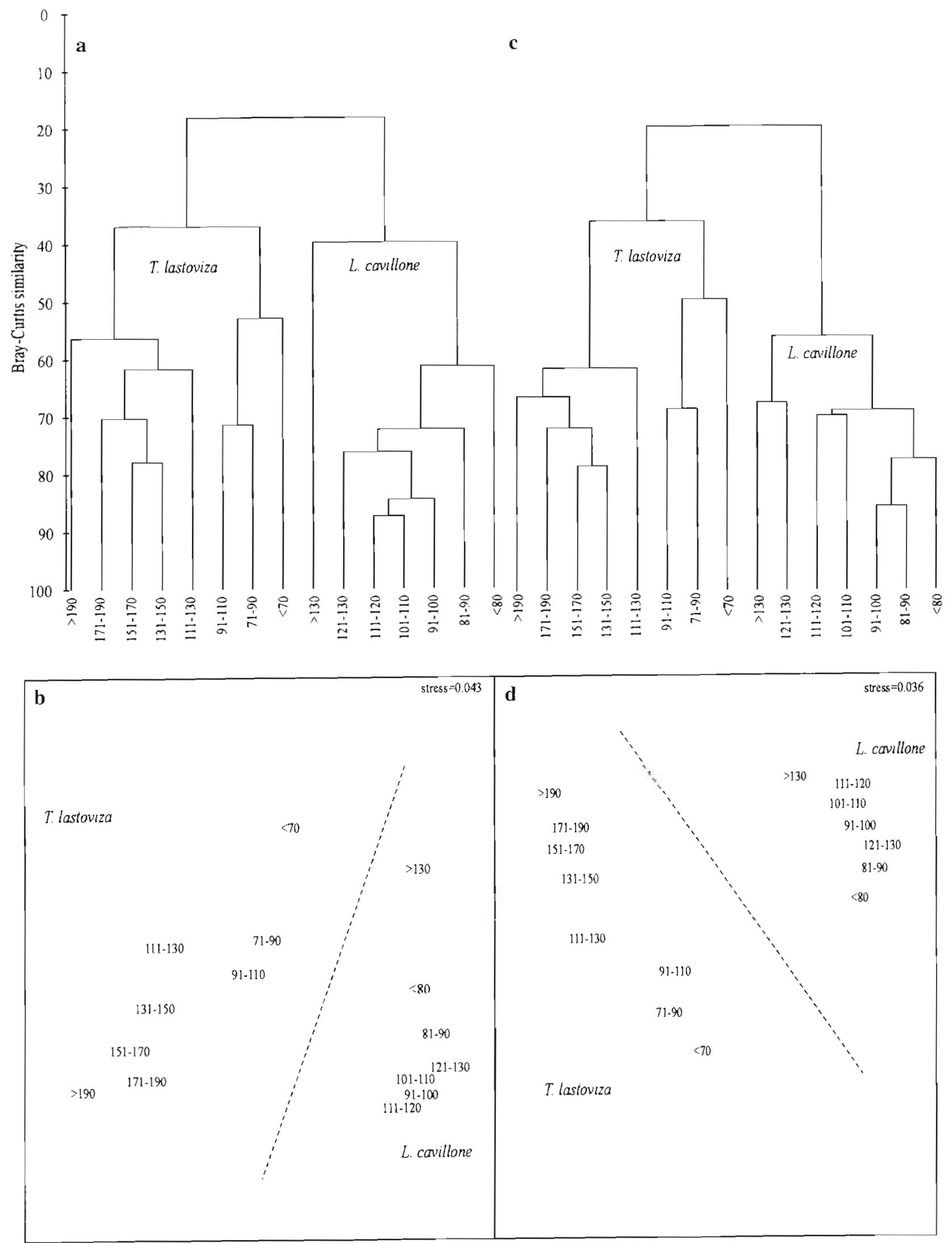

Fig. 4. Classification and ordination of dietary samples by number (a, b) and by weight ( $\mathrm{c}$, d) for both Trigloporus lastoviza (group I) and Lepidotrigla cavillone (group II) 


\section{DISCUSSION}

The results of the present study indicate that there are species differences in preference and utilization of prey related to species distribution patterns. Trigloporus lastoviza, which exhibited the most restricted distribution, appeared to have a broader trophic niche than Lepidotrigla cavillone, which occurred in a wider depth range. The patterns of resource use exhibited by each fish species were consistent during the species' life span and did not change during ontogeny.

The distribution patterns of the triglids on the Cretan continental shelf exhibited non-random habitat utilization. Although previous studies reported that these species do not show discrete bathymetric differences in many areas (Papaconstantinou 1983, Tsimenides et al. 1991, 1992), they did exhibit a degree of habitat segregation, with Trigloporus lastoviza preferring shallow algae-covered areas, while Lepidotrigla cavillone preferred areas with more mud cover over a greater depth range. Furthermore, $T$. lastoviza displayed a significant shallow depth selection during all seasons, while $L$. cavillone occurred throughout the exploited area and no significant effect of season on the depths occupied was found. Thus, although both $T$. lastoviza and $L$. Cavillone cooccur on the Cretan continental shelf, there is a partial partitioning of habitats between the 2 species in these waters. Depth is correlated with temperature, and the tendency for T. lastoviza to select relatively warm temperatures compared to those available is consistent with its bathymetric distribution in the study area.

Papaconstantinou (1983) reported that on the western coasts of the Aegean Sea the juveniles of both species occur at shallow depths on Posidonia oceanica meadows and migrate to deeper waters when they complete their first year of growth, while they are still immature. The significant relationships between the maximum and minimum total length and depth for Lepidotrigla cavillone during summer was due to the recruitment in $P$. oceanica beds and, consequently, smaller individuals
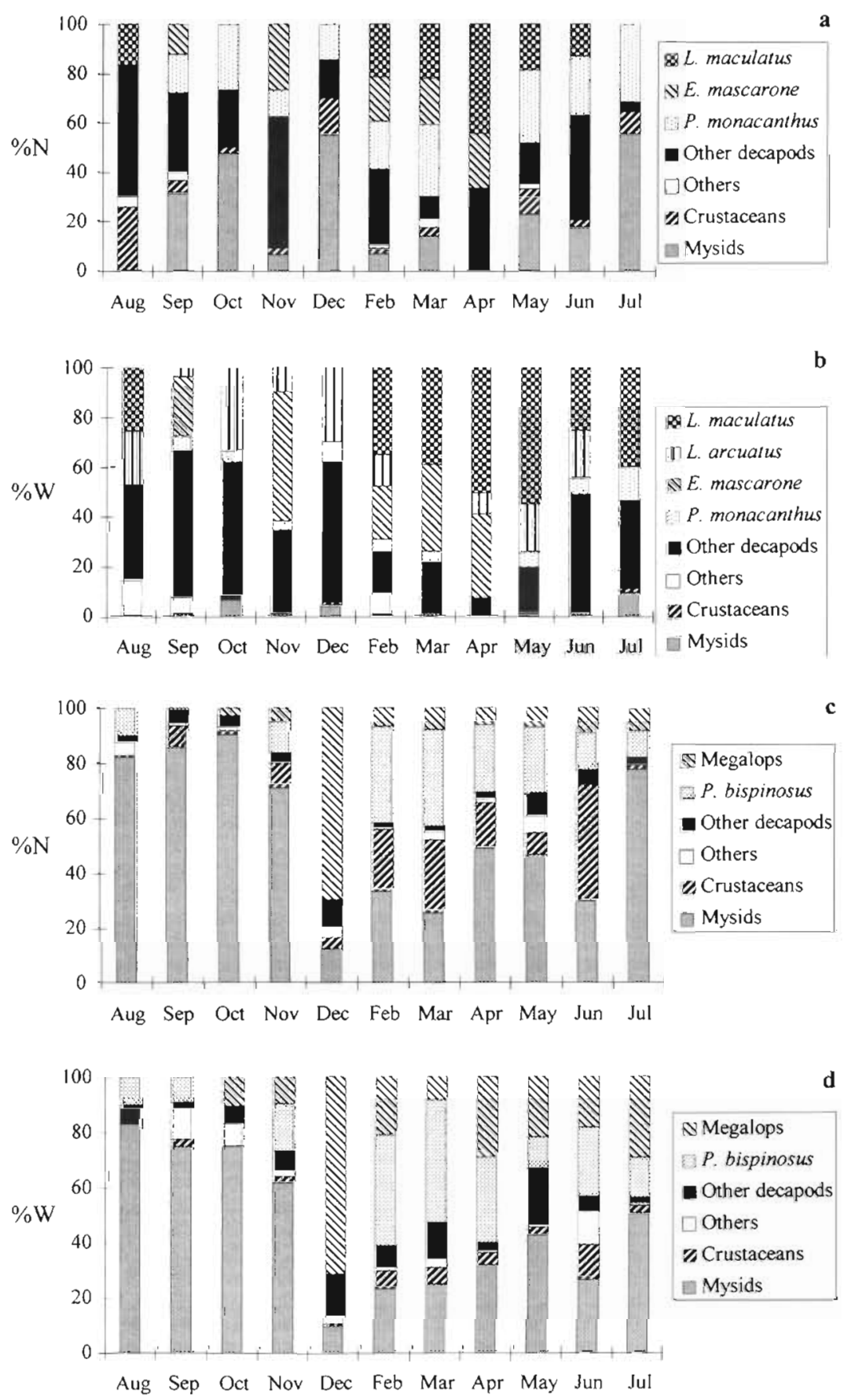

Fig. 5. Monthly variations of the percentage contribution by number $(\% \mathrm{~N})(\mathrm{a}, \mathrm{c})$ and by weight $(\% \mathrm{~W})(\mathrm{b}, \mathrm{d})$ of the major prey groups and species in the diets of $(a, b)$ Trigloporus lastoviza and (c, d) Lepidotrigla cavillone

tended to be found in shallower waters. According to Colloca et al. (1997), migration of $L$. cavillone is associated with their spawning activity, but before gonad maturation juveniles reach bottoms deeper than the spawning grounds. There is evidence from the present study that for L. cavillone, at least during spring, individuals of intermediate size appeared to be distributed deeper than 

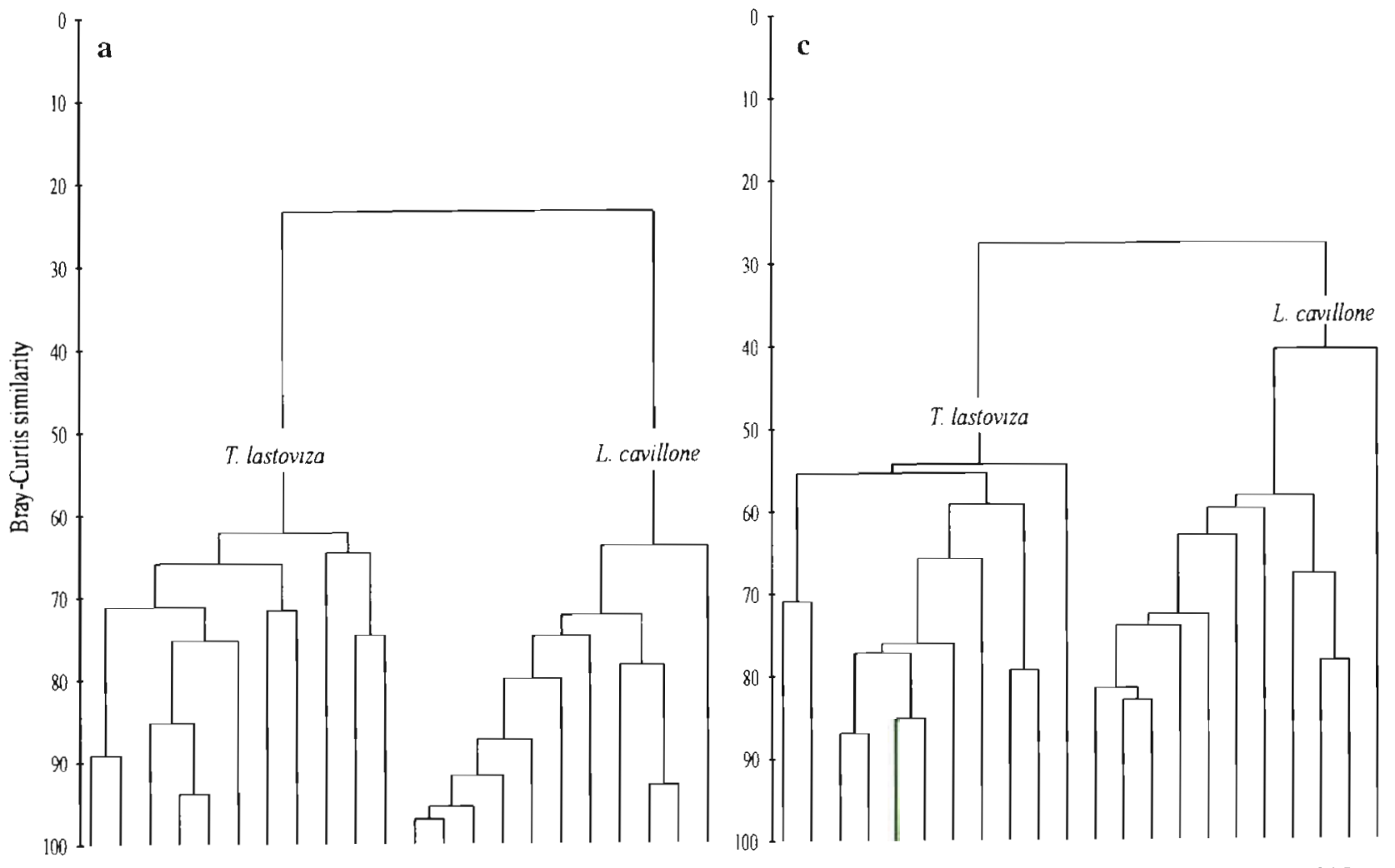

Jul Jun MayApr MarAugSep Oct Feb Dec Nov Jul Jun AugiMay Sep Ocl NovDec Feb MarApr Jul Jun May Apr Feb Sep AugOcl MarDex Nov Jul Jun Nov May AugOcl Sep Mar Feb Dec Apr

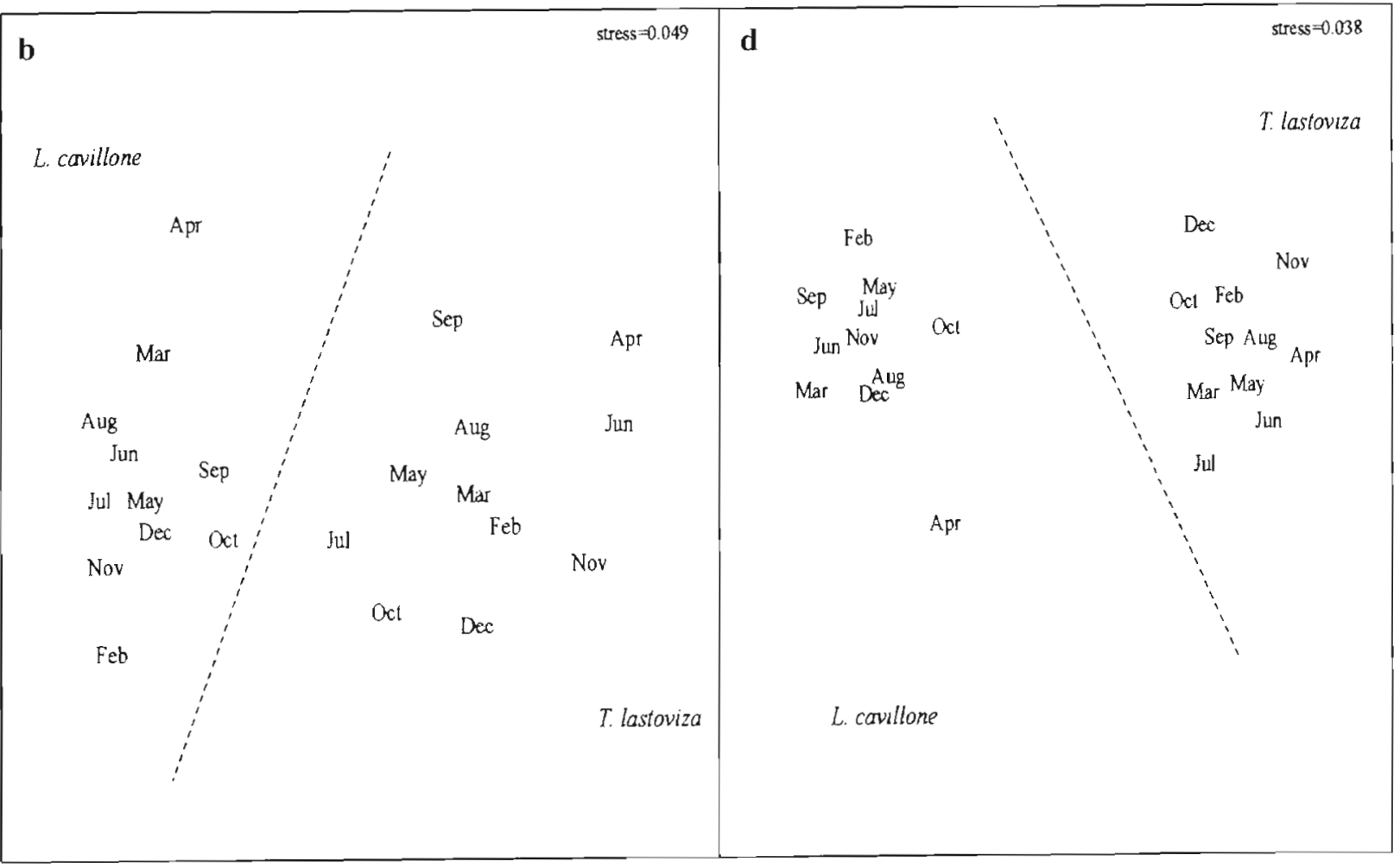

Fig. 6. Classification and ordination of monthly dietary samples by number $\left(\mathrm{a}\right.$, b) and by weight $\left(\mathrm{c}_{\mathrm{i}} \mathrm{d}\right)$ for both Trigloporus lastoviza (group I) and Lepidotrigla cavillone (group II) 
Table 3. Dietary overlap for Trigloporus lastoviza and Lepidotrigla cavillone. Ranges in parentheses: $95 \%$ bootstrap confidence intervals

\begin{tabular}{|ccccc|}
\hline $\begin{array}{c}\text { Biomass } \\
\text { T. lastoviza }\end{array}$ & & \multicolumn{2}{c|}{$\begin{array}{r}\text { Numerical abundance } \\
\text { T. Lastoviza }\end{array}$} \\
\cline { 1 - 2 } L. cavillone $\begin{array}{c}0.36 \\
(0.27-0.48)\end{array}$ & & L. cavillone & $\begin{array}{c}0.41 \\
(0.33-0.51)\end{array}$ \\
\hline
\end{tabular}

bigger fish. The lack of any relationship between minimum and maximum fish size and depth from this study did not indicate a general smaller-shallower or biggerdeeper effect (MacPherson \& Duarte 1991). Hence, more detailed studies are needed to examine the trends between fish size and depth of both triglids.

Bathymetric trends in demersal fish distribution may be linked to physical factors correlated with depth, such as temperature, salinity and bottom type, but biotic factors, in particular prey abundance, have also been shown to be important determinants of distribution (Fry 1971, Nakken \& Raknes 1987, Rose \& Leggett 1989, MacPherson \& Duarte 1991). The composition of food suggests that both triglids are benthophagous species that rely on epibenthic invertebrates, mainly decapods and mysids. Other studies have also confirmed that crustacean decapods and mysids were major components in the diet of triglids (Ross 1977 . 1978, Meyer \& Smale 1991, Colloca et al. 1994). However, the species segregate their feeding niches by utilizing different prey species. Among prey species, those which predominated in the diet of Trigloporus lastoviza were absent in the diet of Lepidotrigla cavilIone. Similarly, the principal prey of $L$. cavillone did not occur in the diet of $T$. Iastoviza. Even within the group of small crustaceans which contributed less in their diets, differences in the extent to which the 2 species feed on particular prey species can be identified. Dietary breadth, as measured by Levin's index, indicated that despite the broad range of prey types found in the diets of the examined fish species, they tended to be specialized in their food preferences. Not only are more prey species found in T. lastoviza than in $L$. Cavillone stomachs, but $T$. lastoviza has a diet dominated by more prey species; that is, it can be considered more generalist than $L$. cavillone.

Comparisons between the dietary composition of the different length classes revealed that both species undergo changes in their feeding habits during ontogeny; however, almost the same prey taxa occurred in the stomachs of all size classes for each species. Nonetheless, there were differences in the relative proportions of each taxon. Clearly, trophic ontogeny in both triglids proceeds as a continuum of dietary changes rather than by distinct segregation of food resources between size classes. Furthermore, there was a general tendency for the mean number of prey eaten to decrease and for food bulk to increase with size; instead of consuming increasing numbers of small prey, fish began to take smaller numbers of larger prey. There is evidence that the size-related differences in the diet reflect changing food preference with size and the ability of larger individuals to capture larger animals as prey. Although the mean size of prey utilized by these triglids differs, both species exploited relatively small prey correlated with their small mouth gape (Labropoulou \& Markakis 1998) and could be classified to 'scitulus' mode predators according to Ross (1977). Feeding intensity is positively related to the degree and index of fullness and negatively related to the percentage of empty stomachs (Bowman \& Bowman 1980). The low vacuity index values throughout the sampling period indicate that feeding intensity is high for both species, in spite of the fact that both showed the greatest level of feeding activity during the morning (Labropoulou 1995).

Although the species studied are spatially and temporally sympatric, dietary overlap was relatively low, suggesting that food resources were well partitioned for these species when they coexisted, at least over the size ranges examined. Moreover, Trigloporus lastoviza and Lepidotrigla cavillone showed a further trend towards segregation of their feeding niches by consuming significantly different prey sizes. Although the overall external morphology of these species is quite similar (Whitehead et al. 1986), the analysis of their morphological characteristics revealed that there are significant differences in all the characteristics related to feeding, such as mouth gape, number of gill rakers and intestine length (Labropoulou \& Markakis 1998). As a consequence, $L$. cavillone, with a larger relative mouth gape and short and relatively sparse gill rakers, is clearly more efficient at feeding on larger animals, while r. lastoviza utilizes smaller and less mobile prey items, including species that were not found in the diet of $L$. cavillone. Norton's (1991) experimental work supported the hypothesis that dietary differences in cottids are in part due to differences in relative mouth size through the influence of mouth size in feeding performance. Ross (1977) showed that sea robins with high habitat overlap tended to differ in prey size selection, and Werner (1979) reported that species characteristics such as body size and feeding apparatus morphology are correlated with the efficient use of different food sizes.

There have been many investigations into the demersal fish communities of marine fish species which demonstrated a considerable level of food specialization between coexisting related species (Tyler 1972, Stoner 1979, MacPherson 1981, Livingston 1982, Gibson \& Ezzi 1987, Harmelin-Vivien et al. 1989). Optimal foraging theory predicts a specialization in diet as the 
absolute abundance of preferred prey types increases (Pyke 1984, Hart 1986). Analysis of the macrobenthic communities on the Cretan continental shelf has shown that the density of the prey organisms is very low in the benthos (Karakassis \& Eleftheriou 1997) and therefore a correspondingly low contribution in the stomachs might have been expected. However, it is very possible that microcrustaceans are not quantitatively represented in the macrobenthic samples taken by means of a Smith-McIntyre grab because they are mobile, sparsely distributed and susceptible to loss from the samples resulting from pressure waves (Word 1978, Hyatt 1979). Therefore very few data are available on the abundance of the prey organisms in the environment and it is not clear whether the fish species in this study preferentially select their prey or they exploit the food resources in a density-dependent manner.

Since Trigloporus lastoviza and Lepidotrigla cavillone have access to the same prey, their differences in diet when in the same habitat must reflect differences in some other factors, such as feeding behaviour and their adaptation to different habitats. T. lastoviza was found to select shallow depths, where the diversity of benthic species is the highest, whilst the distribution of L. cavillone over deeper waters coincides with the remarkable decline in benthic species richness and diversity towards the outer shelf (Karakassis \& Eleftherou 1997). Perhaps this is the major reason for the observed dietary patterns over the depth range in which the 2 species coexist. On the other hand the narrow feeding niche of $L$. cavillone allows the species to inhabit deeper substrates where food availability and species diversity is relatively low, while the wider feeding niche of $T$. lastoviza could constrain its distribution to shallower more productive waters.

Habitat-related factors causing shifts in feeding modes may be constrained to some extent by intrinsic species-typical characteristics which delimit a fundamental search strategy. Mendelson (1975) suggested that there are 2 basic alternatives available for the location and capture of prey: (1) Predators are adapted to the capture of specific kinds of prey. They inhabit certain places because their prey generally reside there. (2) Predators are adapted to particular habitats, to regions in which they function most effectively. In these regions they prey indiscriminately on whatever animals of a suitable size are available. The results from the present study indicate that the former alternative best explains the feeding mode exhibited by Lepidotrigla cavillone, whereas Trigloporus lastoviza appears to utilize a habitat-related feeding mode. It should be pointed out that, although it is tempting to conclude that a particular species may be a habitat-oriented or a food-type-oriented predator, it is also possible that some species are flexible enough to shift from one mode to the other (Miller 1979). Whether or not the examined species could switch to a different mode is not known, but this seems unlikely given the information available from this study. Feeding flexibility and the parameters along which that flexibility is manifest result from the long-term influence of natural selection and the degree of rigidity of the constructional constraints imposed by phylogeny. Such parameters may include resource availability and prey profitability as well as threat of predation and behavioural flexibility during feeding performance. Furthermore, the feeding mode of each species may not have evolved under the current resource availability but under trophic conditions of a habitat differing from the present one.

In summary, the triglids Trigloporus lastoviza and Lepidotrigla cavillone are partitioned to a certain extent by water depth on the Cretan continental shelf. Species differences in preference and utilization of prey are related to their distributional patterns. In particular, $T$. lastoviza, which exhibited the most restricted distribution, appeared to have broader trophic niche than L. cavillone, which occurred in a wider depth range. The results suggest that the ability of these species to exploit particular habitats and/or specific prey characteristics is an important feature of predator foraging that allows them to segregate their feeding niche at the depth range over which they co-occur.

\section{LITERATURE CITED}

Berg J (1979) Discussion of methods of investigation the food of fishes with reference to a preliminary study of the prey of Gobiusculus flavencens. Mar Biol 50:263-273

Booth AJ (1997) On the life history of the lesser gurnard (Scorpaeniformes: Triglidae) inhabiting the Agulhas Bank, South Africa. J Fish Biol 51:1155-1173

Bowen SH (1983) Quantitative description of the diet. In: Nielsen LA, Johnson DL (eds) Fisheries techniques. Am Fish Soc, Bethesda, p 325-336

Bowman RE, Bowman EW (1980). Diurnal variation in the feeding intensity and catchability of silver hake (Merluccius bilineans). Can J Fish Aquat Sci 37:1565-1572

Caragitsou E, Papaconstantinou C (1990) Food and feeding habits of large scale gurnard, Lepidotriglla cavillone (Triglidae) in Greek seds. Cybium 14:95-104

Carrothers PJG (1980) Estimation of trawl door spread from wing spread. J Northw Atl Fish Sci 1:81-89

Colloca F, Ardizzone GD, Gravina MF (1994) Trophic ecology of gurnards (Pisces: Triglidae) in the Central Mediterranean Sea. Mar Life 4:45-57

Colloca F, Cardinale M. Ardizzone GD (1997) Biology, spatia! distribution and population dynamics of Lepidotrigla cavillone (Pisces: Triglidae) in the Central Tyrrhenian Sea. Fish Res 32:21-32

Efron B, Tibshirani R (1986) Bootstrap methods for standard errors, confidence intervals and other measures of statistical accuracy. Stat Sci 1:54-77

Field JG, Clarke KR, Warwick RM (1982) A practical strategy for analysing multispecies distribution patterns. Mar Ecol Prog Ser 8:37-52 
Fry FEJ (1971) The effect of environmental factors on the physiology of fish. In: Hoar WS, Randall DJ, Brett JR (eds) Fish physiology, Vol VI. Academic Press, New York, p $1-98$

Gibson RN, Ezzi IA (1987) Feeding relationships of a demersal fish assemblage on the west coast of Scotland. J Fish Biol 31:55-69

Hall SJ, Raffaelli D, Basford DJ, Robertson MR, Fryer R (1990) The feeding relationships of the larger fish species in a Scottish sea loch. J Fish Biol 37:775-791

Harmelin-Vivien HL, Kaim-Malka RA, Ledoyer M, JakobAbraham SS (1989) Food partitioning among scorpaenid fishes in Mediterranean seagrass beds. J Fish Biol 34: $715-734$

Hart PJB (1986) Foraging in teleost fishes. In: Pitcher TJ (ed) The behaviour of teleost fishes. Johns Hopkins Univ Press, Baltimore, MD, p 211-235

Hurlbert SH (1978) The measurement of niche overlap and some relatives. Ecology 59:67-77

Hyatt KD (1979) Feeding strategy. In: Hoar WS, Randall DJ (eds) Fish physiology, Vol VIII. Academic Press, New York, p 71-119

Hyslop EJ (1980) Stomach contents analysis - a review of methods and their application. J Fish Biol 17:411-429

Karakassis I, Eleftheriou A (1997). The continental shelf of Crete: structure of macrobenthic communities. Mar Ecol Prog Ser 160:185-196

Keast A. (1978) Trophic and spatial interrelationships in the fish species of an Ontario temperature lake. Environ Biol Fish 3:7-31

Krebs CJ (1989) Ecological methodology. Harper \& Row, New York

Labropoulou M (1995) Feeding ecology of the demersal fish species in Iraklion Bay. PhD thesis, University of Crete, Iraklion

Labropoulou M, Markakis G (1998) Morphological-dietary relationships within two assemblages of marine demersal fishes. Environ Biol Fish 51:309-319

Langton RW (1982) Diet overlap between Atlantic cod Gadus morhua, silver hake, Merluccius bilinearis and fifteen other Northwest Atlantic finfish. Fish Bull 80: $745-759$

Livingston RJ (1982) Trophic organization of fishes in a coastal seagrass system. Mar Ecol Prog Ser 7:1-12

MacPherson E (1981) Resource partitioning in a Mediterranean demersal fish community. Mar Ecol Prog Ser 4 $183-193$

MacPherson E, Duarte CM (1991) Bathymetric trends in demersal fish size: is there a general relationship? Mar Ecol Prog Ser 71:103-112

Mendelson J (1975) Feeding relationships among species of Notropis (Pisces: Cyprinidae) in a Wisconsin stream. Ecol Monogr 45:199-230

Meyer M, Smale MJ (1991) Predation patterns of demersal teleosts from the south and west coasts of South Africa. 2. Benthic and epibenthic predators. S Afr $J$ Mar Sci 11: 409-442

Middleton RW, Musick JA (1986) The abundance and distribution of the family Macrouridae (Pisces: Gadiformes) in the Norfork Canyon area. Fish Bull 84:35-62

Miller RJ (1979) Relationships between habitat and feeding mechanisms in fishes. In: Stroud R, Clepper H (eds) Predator-prey systems in fisheries management. Sport Fishing Inst, Washington, DC, p 269-280

Mittelbach GG (1981) Foraging efficiency and body size: a study of optimal diet and habitat use by bluegills. Ecology $62: 1370-1386$
Nakken O, Raknes A (1987) The distribution and growth of Northeast Arctic cod in relation to bottom temperatures in the Barents Sea, 1978-1984. Fish Res 5:243-252

Norton SF (1991) Habitat use and community structure in an assemblage of cottid fishes. Ecology 72:2181-2192

Osenberg GW, Mittelbach GG, Wainwright PC (1992) Twostage life histories in fish: the interaction between juvenile competition and adult performance. Ecology 73: $255-267$

Papaconstantinou C (1983) Observations on the ecology of gurnards (Pisces: Triglidae) of the Greek seas. Cybium 7: $71-88$

Perry RI, Smiths SJ (1994) Identifying habitat associations of marine fishes using survey data: an application to the Northwest Atlantic. Can J Fish Aquat Sci 51:589-602

Pyke GH (1984) Optimal foraging theory: a critical review. Annu Rev Ecol Syst 15:523-575

Rose GA, Legget WC (1988) Atmosphere-ocean coupling and Atlantic cod migrations: effects of wind - forced variations in sea temperatures and currents on nearshore distributions and catch rates of Gadus morhua. Can J Fish Aquat Sci 45:1234-1243

Rose GA, Leggett WC (1989) Interactive effects of geophysically-forced sea temperatures and prey abundance on mesoscale coastal distributions of a marine predator, Atlantic cod (Gadus morhua). Can J Fish Aquat Sci 46 $1904-1913$

Ross ST (1977) Patterns of resource partitioning in sea robins (Pisces: Triglidae) Copeia 1977:561-571.

Ross ST (1978) Trophic ontogeny of the leopard sea robin, Prinotus scitulus (Pisces: Triglidae). Fish Bull 76:225-234

Ross ST (1986) Resource partitioning in fish assemblages: a review of field studies. Copeia 1986:352-388

Sale PF (1979) Habitat partitioning and competition in fish communities. In: Stroud R, Clepper H (eds) Predator-prey systems in fisheries management. Sport Fishing Inst, Washington DC, p 323-331

Schluter D (1994) Experimental evidence that competition promotes divergence in adaptive radiation. Science 266: $798-801$

Schoener TW (1974) Resource partitioning in ecological communities. Science 185:27-39

Stefanescu C, Rucabado J, Lloris D (1992) Depth-size trends in western Mediterranean demersal deep-sea fishes. Mar Ecol Prog Ser 81:205-213

Stoner AW (1979) Species-specific predation on amphipod Crustacea by the pinfish Lagodon rhomboides: mediation by macrophyte standing crop. Mar Biol 55:201-207

Swain DP, Krammer DL (1995) Annual variation in temperature selection by Atlantic cod Gadus morhua in the southern Gulf of St. Lawrence, Canada, and its relation to population size. Mar Ecol Prog Ser 116:11-23

Tsimenides N, Machias A, Kallianiotis A (1992) Distribution patterns of triglids (Pisces: Triglidae) on the Cretan shelf (Greece) and their specific associations. Fish Res 15: $83-103$

Tsimenides N, Tserpes G, Machias A, Kallianiotis A (1991) Distribution of fishes on the Cretan shelf. J Fish Biol 39: 661-672

Tyler AV (1972) Food resource division among northern, marine demersal fishes. J Fish Res Board Can 29:997-1003

Wallace RK Jr (1981) An assessment of diet-overlap indexes. Trans Am Fish Soc 110:72-76

Werner EE (1979) Niche partitioning by food size in fish communities. In: Stroud R, Clepper H (eds) Predator-prey systems in fisheries management. Sport Fishing Inst, Washington, $\mathrm{DC}, \mathrm{p} 311-322$ 
Werner EE (1980) Niche theory in fisheries ecology. Trans Am Fish Soc 109:254-260

Werner EE, Gilliam JF (1984) The ontogenetic niche and species interactions in size-structured populations. Annu Rev Ecol Syst 15:393-425

Werner EE, Gilliam JF, Hall F, Mittelbach GG (1983) An experimental test of the effects of predation risk on habitat use in fish. Ecology 64:1540-1548

Werner EE, Hall DJ (1979) Foraging efficiency and habitat switching in competing sunfishes. Ecology 60 $256-264$

Editorial responsibility: Otto Kinne (Editor),

Oldendorf/Luhe, Germany
Werner EE, Mittelbach GG (1981) Optimal foraging: field tests of diet choice and habitat switching. Am Zool 21:813-829 Whitehead PJP, Bauchot ML, Hureau JC, Nielsen J, Tortonese $\mathrm{E}$ (eds) (1986) Fishes of the North-Eastern Atlantic and the Mediterranean. UNESCO, Paris

Word JQ (1978) An evaluation of benthic invertebrate sampling devices for investigating feeding habits of fish. In: Lipovsky SJ, Simenstand CA (eds) Fish food habit studies. University of Washington, Seattle, p 43-55

Zar JH (1984) Biostatistical analysis. Prentice-Hall, Englewood Cliffs

Submitted: May 26, 1998; Accepted: July 31, 1998

Proofs received from author(s): October 19, 1998 